\title{
Penyelesaian Sengketa Kewenangan Konstitusional Lembaga Negara sebagai Salah Satu Kewenangan Mahkamah Konstitusi
}

\author{
Sri Hastuti Puspitasari \\ Fakultas Hukum Universitas Islam Indonesia \\ J1. Tamansiswa No. 158 Yogyakarta \\ srihastuti@fh.uii.ac.id
}

\begin{abstract}
The problem formulations of this research are: first, how is the structure of state institutions in Indonesian constitutional system according to the 1945 Constitution of Indonesian Republic? Second, what are the issues in dealing with the conflicts related to state institutions' authority in Constitutional Court of Indonesian Republic? This research is aimed at: first, analyzing the structure of state institutions in Indonesian constitutional system according to the 1945 Constitution of Indonesian Republic. Second, analyzing and identifying the issues in dealing with any conflicts related to state institutions' authority in Constitutional Court of Indonesian Republic. This research was a normative legal research. The data analysis was done by using descriptive-qualitative approach. The findings show that: first, the structure of state institutions in Indonesian constitutional system after the amendment of the 1945 Constitution of Indonesian Republic has equal positions since the position of MPR (People's Consultative Assembly) as the highest state institution has been abolished. After the amendment of the 1945 Constitution, Indonesian constitutional system no longer upholds the teaching of distribution of power, but separation of power. Second, the issues in dealing with the conflicts related to state institutions' authority in Constitutional Court are the fact that there are differences in each decisions in SKLN, i.e. Decision No. 068/SKLN-III/2004, Constitutional Court Rejects the Petitions of Petitioners. Decision No. 3/SKLN-X/2012, Constitutional Court Grants. And Decision No. 2/SKLN-X/2012 Constitutional Court states Not Granted.
\end{abstract}

Keywords: Conflict, state institutions, constitutional court

\begin{abstract}
Abstrak
Penelitian ini merumuskan permasalahan sebagai berikut: pertama, bagaimana struktur lembaga negara dalam sistem ketatanegaraan Indonesia menurut UUD Negara RI 1945? Kedua, apa problematika dalam penyelesaian sengketa kewenangan lembaga negara di Mahkamah Konstitusi Republik Indonesia? Penelitian ini bertujuan: pertama, menganalisis struktur lembaga negara dalam sistem ketatanegaraan Indonesia menurut UUD Negara RI 1945. Kedua, menganalisis dan mengidentifikasi problematika dalam penyelesaian sengketa lembaga negara di Mahkamah Konstitusi RI. Penelitian ini adalah penelitian hukum normatif. Pengolahan dan analisis bahan hukum dengan cara deskriptif-kualitatif. Hasil penelitian menyimpulkan bahwa: pertama, struktur lembaga negara dalam sistem ketatanegaraan RI pasca perubahan UUD Negara RI 1945 memiliki kedudukan yang sederajat karena kedudukan MPR sebagai lembaga tertinggi negara sudah dihapuskan. Setelah perubahan Undang Undang Dasar 1945, sistem ketatanegaraan Indonesia tidak lagi menganut paham distribution of power tetapi separation of power. Kedua, problematika dalam penyelesaian sengketa kewenangan lembaga negara di MK adalah terdapat perbedaan di setiap putusan dalam SKLN, yakni Putusan No. 068/SKLN-III/2004, Mahkamah Konstitusi Menolak Permohonan para Pemohon. Putusan Perkara No. 3/SKLN-X/2012, Mahkamah Konstitusi Menerima. Dan Putusan Perkara No. 2/SKLNX/2012 Mahkamah Konstitusi menyatakan Tidak Diterima.
\end{abstract}

Kata kunci: Sengketa, lembaga negara, mahkamah konstitusi 


\section{Pendahuluan}

Adanya perubahan kedudukan MPR menyebabkan terjadinya perubahan pada tatanan hubungan antar lembaga negara. Hubungan antar lembaga negara tidak lagi terstruktur secara hirarkis melainkan tersusun secara fungsional, dimana konstitusi memberikan fungsi kepada tiap-tiap lembaga negara. Artinya dengan perubahan tersebut, akan mempertegas dianutnya sistem pemisahan kekuasaan dan prinsip check and balance di antara lembaga-lembaga tinggi negara. Jika sebelum amandemen kedaulatan rakyat sepenuhnya berada di tangan MPR, maka kini menurut amandemen UUD 1945 kedaulatan rakyat di distribusikan ke berbagai lembaga negara, dalam hal ini MPR, DPR, DPD, MA, MK, KY, BPK dan Presiden. Dengan prinsip check and balance ini, maka kekuasaan negara dapat diatur, dibatasi bahkan dikontrol dengan sebaik-baiknya, sehingga penyalahgunaan kekuasaan oleh aparat penyelenggara negara ataupun pribadipribadi yang kebetulan sedang menduduki jabatan dalam lembaga-lembaga negara yang bersangkutan dapat dicegah dan ditanggulangi dengan sebaikbaiknya.

Check and balances dalam hal ini juga dapat disebut dengan sistem perimbangan kekuasaan, ${ }^{1}$ atau secara harfiah dapat diartikan sebagai sistem aturan yang menegaskan adanya mekanisme saling kontrol di antara cabang kekuasaan baik legislatif, eksekutif, maupun yudikatif yang didesain untuk mencegah terkonsentrasinya kekuasaan dalam satu cabang sehingga mendominasi cabang kekuasaan yang lain. ${ }^{2}$ Secara konseptual, prinsip check and balaces dimaksudkan agar tidak terjadi overlapping atau tumpang tindih antara kewenangan lembaga negara sehingga kekuasaan dalam negara haruslah diatur dengan seksama. Selain itu, check and balances juga bertujuan untuk mencegah dan meminimalisir terjadinya 'abuse of power' dalam praktek bernegara. ${ }^{3}$ Dalam rangka menjamin bahwa masing-masing kekuasaan tidak mempunyai batas

\footnotetext{
${ }^{1}$ Ni'matul Huda, Lembaga Negara Dalam Masa Transisi Demokrasi, UII Press, Yogyakarta, 2007, hlm. 75.

2 Peter Butt (eds), Butterworths Concise Australian Legal Dictionary, dikutip oleh Masnur Marzuki dalam "Pemisahan Kekuasaan dan Prinsip Check and Balances dalam Undang-Undang Dasar Negara Republik Indonesia Tahun 1945", makalah disampaikan dalam acara Pendidikan Kesadaran Berkonstitusi, diselenggarakan oleh PSHK FH UII bekerjasama dengan Hanns Seidel Foundation, tanggal 18 Desember 2010, hlm. 10.

${ }^{3}$ Ibid.
} 
kekuasaan maka sistem check and balances sangat diperlukan, karena dalam check and balances masing-masing kekuasaan saling mengawasi dan mengontrol. ${ }^{4}$

Pada masa reformasi, struktur ketatanegaraan Indonesia juga diwarnai dengan munculnya lembaga-lembaga atau komisi-komisi independen yang membantu, mengontrol dan mengawasi jalannya pemerintahan. Semacam Komisi Pemberantasan Korupsi, Komisi Pemilihan Umum, Komisi Nasional Hak Asasi Manusia, Lembaga Perlindungan Saksi dan Korban dan masih terdapat beberapa lembaga lainnya yang mempunyai fungsi untuk membantu terselenggaranya sistem pemerintahan yang baik. Munculnya lembaga-lembaga ini merupakan pengejawantahan dari sistem check and balances yang dianut di Indonesia, sehingga antara satu lembaga dengan lembaga lainnya dapat saling kontrol dan tidak terjadi penyalahgunaan kekuasaan.

Meskipun pembagian kekuasaan seperti yang dikemukakan oleh Montesquieu dibagi dalam tiga cabang kekuasaan, yakni legislatif, eksekutif dan yudikatif ${ }^{5}$ tersebut telah dilakukan dan memunculkan berbagai lembaga-lembaga baru yang mempunyai fungsi untuk menjalankan ataupun mengontrol ketiga kekuasaan tersebut, bukan berarti dalam dataran praktek dan realitanya akan berjalan dengan baik. Potensi sengketa antar lembaga negara cenderung tinggi, dikarenakan hubungan antara satu lembaga dengan lembaga lainnya diikat oleh prinsip check and balances, dimana lembaga-lembaga mempunyai kedudukan yang sedarajat dan saling mengendalikan. Oleh karena posisinya yang sederajat tersebut, ada kemungkinan dalam melaksanakan kewenangannya timbul perselisihan dalam menafsirkan amanat UUD. Maka dari itu, diperlukan organ tersendiri untuk menyelesaikan sengketa antar lembaga negara. Sengketa tersebut, dapat dilakukan melalui mekanisme peradilan tata negara yang ada pada Mahkamah Konstitusi. ${ }^{6}$ Peran strategis Mahkamah Konstitusi dalam memutus sengketa kewenangan lembaga negara berbanding lurus dengan fungsi MK untuk melaksanakan kekuasaan peradilan dalam sistem konstitusi, sebagai

${ }^{4}$ Ibid.

5 Miriam Budiardjo, Dasar-Dasar Ilmu Politik, PT. Gramedia Pustaka Utama, Jakarta, 2006, hlm. 152. Menurut Montesquieu ketiga poros kekuasaan tersebut dapat ditemukan dalam setiap struktur ketatanegaraan di seluruh belahan dunia. Lihat juga dalam Jimly Asshiddiqie, Perkembangan dan Konsolidasi Lembaga Negara Pasca Reformasi, Sinar Grafika, Jakarta, 2010, hlm. 30

${ }^{6}$ Jimly Asshidiqie, Sengketa Kewenangan Antarlembaga Negara, KONPress, Jakarta, 2005, hlm. 11. 
penjaga konstitusi (the guardian of constitution) sekaligus sebagai penafsir konstitusi (the sole interpreter of constitution). ${ }^{7}$ Peran MK dalam memutus sengketa kewenangan lembaga negara sesuai dengan prinsip peran MK dalam menjaga konstitusionalitas pelaksanaan kekuasaan negara. ${ }^{8}$

Sejak 2003 hingga awal 2012, putusan MK tentang SKLN berjumlah 19 (Sembilan belas). Dari 19 (sembilan belas) perkara ini, 1 (satu) di kabulkan, 2 (dua) putusan ditolak, 12 (dua belas) tidak diterima, dan 4 (empat) ditarik kembali. Sebagai contoh perkara yang putusannya tidak diterima adalah Putusan No. 027/SKLN-IV/2006. Objek sengketa dalam perkara tersebut adalah masalah kewenangan pengusulan pengangkatan baik daerah provinsi maupun kabupaten/kota. Dalam hal ini Pemohon mengajukan pengujian terhadap kewenangan Gubernur Sulawesi Tengah yang mengusulkan, mengesahkan sekaligus mengangkat Drs. Piet Inkirwang, M.M. dan Abdul Muthalib Rimi, S.H., M.H. sebagai Bupati dan Wakil Bupati Poso serta melantik mereka tidak dalam sidang paripurna DPRD Kabupaten Poso. Dalam Putusan tersebut, MK memutuskan bahwa Permohonan Pemohon tidak dapat diterima (niet ontvankelijk verklaard) karena objectum litis dari permohonan a quo yaitu masalah kewenangan pengusulan pengangkatan kepala daerah, baik daerah provinsi maupun kabupaten/kota adalah bagian dari substansi undang-undang yang mengatur pemerintahan daerah, in casu UU Pemda. Oleh karena itu objek sengketa dari permohonan a quo bukanlah kewenangan yang diberikan oleh UUD 1945.

Putusan lain yang juga tidak dapat diterima adalah Putusan No. 27/SKLNVI/2008. Objek sengketa mengenai pengujian kewenangan Presiden RI yang mengesahkan hasil Pemilukada Provinsi Maluku Utara yang dianggap inkonstitusional oleh KPU Provinsi Maluku Utara. Dalam konklusinya MK berpendapat bahwa berdasarkan fakta-fakta hukum yang ada dalam persidangan, sepanjang mengenai masalah kedudukan hukum (legal standing) Pemohon, Mahkamah berpendapat bahwa Pemohon tidak mempunyai kedudukan hukum (legal standing) untuk mengajukan permohonan a quo karena tidak memenuhi syarat sebagaimana ditentukan dalam Pasal 24C ayat (1) UUD

\footnotetext{
${ }^{7}$ Jimly Asshiddiqie, Perkembangan dan Konsolidasi..., Op, Cit., hlm. 132.

8 Masnur Marzuki, "Telaah Kritis Kewenangan Mahkamah Konstitusi Dalam Sengketa Kewenangan Lembaga Negara”, Jurnal Konstitusi PSHK-FH Universitas Islam Indonesia, Volume IV No. 1, Juni 2011, hlm. 19.
} 
1945 dan Pasal 61 UU MK. Menurut MK, permohonan Pemohon dilihat dari syarat baik subjectum litis maupun objectum litis-nya, bukanlah lingkup permohonan sengketa kewenangan lembaga negara yang kewenangannya diberikan oleh UUD sebagaimana dimaksud dalam Pasal 24C ayat (1) UUD 1945. Oleh karena itu, MK menyatakan permohonan tidak dapat diterima. Selain dua putusan di atas, masih terdapat beberapa putusan terkait dengan sengketa kewenangan lembaga negara yang menarik untuk di analisis, yakni: Putusan Mahkamah Konstitusi No. 68/SKLN-III/2004, Putusan Mahkamah Konstitusi No. 2/SKLN-X/2012, Putusan Mahkamah Konstitusi No. 3/SKLN-X/2012. Hal yang menarik untuk dikaji baik mengenai proses penyelesaian sengketa kewenangan lembaga negara di Mahkamah Konstitusi, maupun alasan-alasan serta pertimbangan Mahkamah Konstitusi dalam menerima atau menolak permohonan penyelesaian sengketa kewenangan lembaga negara yang diajukan.

\section{Rumusan Masalah}

Berdasarkan latar belakang di atas, maka permasalahan yang diteliti adalah: pertama, bagaimana struktur lembaga negara dalam sistem ketatanegaraan Indonesia menurut UUD Negara RI 1945? Kedua, apa problematika dalam penyelesaian sengketa kewenangan lembaga negara di Mahkamah Konstitusi Republik Indonesia?

\section{Tujuan Penelitian}

Penelitian ini bertujuan: pertama, menganalisis struktur lembaga negara dalam sistem ketatanegaraan Indonesia menurut UUD Negara RI 1945. Kedua, menganalisis dan mengidentifikasi problematika dalam penyelesaian sengketa lembaga negara di Mahkamah Konstitusi Republik Indonesia. 


\section{Metode Penelitian}

Penelitian ini adalah penelitian hukum normatif yaitu penelitian hukum yang dilakukan dengan cara meneliti bahan pustaka. ${ }^{9}$ Bahan hukum primer yang digunakan; yaitu UUD 1945 dan peraturan perundang-undangan terkait, serta putusan Mahkamah Konstitusi No. 68/SKLN-III/2004, Putusan Mahkamah Konstitusi No. 27/SKLN-VI/2008, Putusan Mahkamah Konstitusi No. 2/SKLNX/2012, Putusan Mahkamah Konstitusi No. 3/SKLN-X/2012. Bahan hukum sekunder yang digunakan berupa buku, jurnal, artikel dan literatur lainnya yang berkaitan dengan permasalahan yang dibahas, serta untuk meningkatkan mutu dalam memahami hukum positif yang terdapat dalam bahasan. ${ }^{10}$ Pendekatan yang digunakan dalam penelitian ini yaitu pendekatan yuridis-normatif. Pengolahan dan analisis data yang digunakan adalah deskriptif-kualitatif.

\section{Hasil Penelitian dan Pembahasan}

\section{Struktur Lembaga Negara dalam Sistem Ketatanegaraan RI menurut UUD Negara 1945}

Kedudukan MPR di dalam struktur ketatanegaraan Indonesia merupakan lembaga tertinggi negara, hal ini yang terjadi sebelum amandemen Undang Undang Dasar 1945. Sebutan bagi lembaga tertinggi negara dengan kekuasaan tidak terbatas digunakan sebagai alat antara lain memperbesar kekuasaan presiden di luar ketentuan UUD 1945, seperti TAP MPR yang memberi kekuasaan tidak terbatas kepada presiden demi pembangunan. ${ }^{11}$ Munculnya praktik-praktik yang melanggar UUD 1945 tersebut menyebabkan muncul gagasan pada Sidang Tahunan MPR tahun 2001 memutuskan meniadakan Pasal 1 ayat (2) UUD 1945 yang kemudian diganti menjadi: "Kedaulatan berada di tangan rakyat dan

\footnotetext{
${ }^{9}$ Soerjono Soekamto dan Sri Mamudji, Penelitian Hukum Normatif, Rajawali, Jakarta, 1985, hlm. 15.

${ }^{10}$ Sulistyowati Irianto dan Shidarta (ed.), Metode Penelitian Hukum: Konstelasi dan Refleksi, Yayasan Obor Indonesia, Jakarta, 2009, hlm. 128.

${ }^{11}$ Lihat dalam Tap MPR No. V Tahun 1998, lihat juga dalam Ni'matul Huda, Hukum Tata Negara Kajian Teoritis dan Yuridis terbadap Konstitusi Indonesia, PSH FH UII kerjasama dengan Gama Media, Yogyakarta, 1999, hlm. 71-74.
} 
dilakukan menurut UUD (perubahan ketiga). Perubahan tersebut berimplikasi bahwa MPR tidak lagi berwenang memilih presiden dan wakil presiden karena rakyat yang akan memilih melalui pemilu langsung. Wewenang MPR hanya sebatas melantik presiden dan wakil presiden hasil pemilu. MPR juga tidak berwenang memberhentikan presiden dan wakil presiden pada masa jabatannya kecuali ada usulan dari DPR setelah mendapat pertimbangan dari Mahkamah Konstitusi. ${ }^{12}$

Perubahan menarik lainnya adalah terkait dengan kewenangan fungsi legislasi DPR terjadi pemindahan atau pergeseran kekuasaan membentuk undang-undang dari Presiden kepada DPR. Sesuai dengan Pasal 20 ayat (1) Amandemen UUD 1945 menyatakan:"Dewan Perwakilan Rakyat memegang kekuasaan membentuk undang-undang". Sedangkan sebelumnya (sebelum diamandemen) sesuai ketentuan Pasal 5 ayat (1) UUD 1945: "Presiden memegang kekuasaan membentuk undang-undang dengan persetujuan DPR". Jadi sebelum amandemen Presiden memiliki peran lebih menonjol dari pada DPR dalam membuat undang-undang. Pergeseran kewenangan membentuk undang-undang dari presiden kepada DPR merupakan langkah konstitusional untuk meletakkan secara tepat fungsi-fungsi lembaga negara sesuai bidang tugasnya masing-masing yakni DPR sebagai lembaga pembentuk undang-undang (kekuasaan legislatif) dan presiden sebagai lembaga pelaksana undang-undang (kekuasaan eksekutif). ${ }^{13}$

Selain itu, perubahan UUD 1945 juga melahirkan lembaga baru yakni Dewan Perwakilan Daerah (DPD). Gagasan pembentukan DPD dalam rangka restrukturisasi parlemen Indonesia menjadi dua kamar diadopsikan. Jika ketentuan mengenai DPR diatur dalam Pasal 20, maka keberadaan DPD sebuah lembaga baru ini secara khusus diatur dalam Bab VIIA tentang Dewan Perwakilan Daerah dan terdiri atas dua pasal (Pasal 22C dan Pasal 22D). Perbedaan antara keduanya terletak pada hakikat kepentingan yang diwakilinya masing-masing. DPR dimaksudkan untuk mewakili rakyat, sedang DPD dimaksudkan untuk mewakili daerah-daerah. Pembedaan hakikat ini penting

\footnotetext{
12 Lihat Pasal 3, 6, 37 Undang Undang Dasar RI 1945.

${ }^{13}$ Ni'matul Huda, Hukum Tata Negara.., Op.Cit., hlm. 169.
} 
untuk menghindari pengertian "double representation' atau keterwakilan ganda mengartikan fungsi parlemen yang dijalankan oleh kedua dewan tersebut.

Dewan Perwakilan Daerah mempunyai tiga macam fungsi, yaitu fungsi legislasi, fungsi pertimbangan dan fungsi pengawasan. ${ }^{14}$ DPD dapat mengajukan kepada DPR rancangan serta dapat melakukan pengawasan undang-undang yang berkaitan dengan; otonomi daerah, hubungan pusat dan daerah, pembentukan, pemekaran dan penggabungan daerah, pengelolaan sumber daya alam dan sumber daya ekonomi lainnya serta yang berkaitan dengan perimbangan pusat dan daerah. Dalam fungsi DPD terkait dengan fungsi perimbangan, fungsi ini oleh DPD disampaikan kepada DPR, hal ini berkenaan dengan; Rancangan undang-undang tentang Anggaran Pendapatan dan Belanja Negara, Rancangan Undang-Undang yang berkaitan dengan pajak, pendidikan dan agama. Hasil pengawasan oleh DPD di atas kemudian disampaikan kepada DPR sebagai bahan pertimbangan untuk ditindaklanjuti. 15

Indonesia sebagai negara yang menganut sistem presidensiil ${ }^{16}$ dalam pemerintahan Indonesia telah menempatkan Presiden dalam fungsi sebagai Kepala Negara sekaligus sabagai Kepala Pemerintahan. ${ }^{17}$ Kekuasaan Presiden dalam bidang pemerintahan diatur dalam ketentuan Pasal 4 ayat (1) yang berbunyi: "Presiden Republik Indonesia memegang kekuasaan pemerintahan menurut Undang-undang Dasar". Selain menjalankan kekuasaan eksekutif,

14 Fungsi legislasi diatur dalam Pasal 22D, fungsi legislasi diatur dalam ayat (1) dan ayat (2). Fungsi Pertimbangan diatur dalam UUD 1945 Pasal 22 D ayat (2), Fungsi Pengawasan tercantum pada Perubahan Ketiga UUD 1945 Pasal 22D ayat (3).

15 Janedjri M. Gaffar dkk, Dewan Perwakilan Daerah dalam Sistem Ketatanegaraan RI, Jakarta, 2003, hlm. 4647.

16 Beberapa ciri penting sistem pemerintahan presidensil adalah: Presiden dan Wakil Presiden tidak bertanggung jawab kepada parlemen, melainkan langsung bertanggung jawab kepada rakyat. Presiden dan wakil presiden hanya dapat diberhentikan dari jabatannya karena alasan pelanggaran hukum yang biasanya dibatasi pada kasus-kasus tindak pidana tertentu dan tindakan pengkhianatan negara dan pelanggaran yang nyata terhadap konstitusi. Dalam hubungannya dengan lembaga parlemen, Presiden tidak tunduk pada parlemen, tidak dapat membubarkan parlemen, dan sebaliknya parlemen juga tidak dapat menjatuhkan presiden dan membubarkan kabinet sebagaimana dalam praktek sistem parlementer. Dalam sistem ini, tidak dikenal adanya pembedaan antara fungsi kepala negara dan kepala pemerintahan. Sedangkan dalam sistem parlementer, perbedaan dan bahkan pemisahan kedua jabatan kepala negara dan kepala pemerintahan itu merupakan suatu kelaziman dan keniscayaan.

17 Dalam konteks pengertian negara, prinsip "the rule of law", dapat dikatakan bahwa secara simbolik, yang dinamakan kepala negara dalam sistem Presidensil itu adalah konstitusi. Dengan perkataan lain, kepala negara dari negara konstitutional Indonesia adalah Undang-Undang Dasar, sedangkan Presiden dan Wakil Presiden dan wakilnya beserta semua lembaga negara atau subyek hukum tatanegara lainnya tunduk kepada konstitusi sebagai "the symbolic head of state" itu. Oleh karena itu, dalam sistem kenegaraan yang dapat kita sebut "constitutional democratic republic" kedudukan konstitusi bersifat sangat sentral. Konstitusi pada dasarnya merupakan kepala negara yang sesungguhnya. 
Presiden juga menjalankan kekuasaan membentuk peraturan perundangundangan. Kekuasaan yang berkaitan dengan penegakkan hukum (grasi, amnesti dan abolisi) ${ }^{18}$ dan lain sebagainya.

Perubahan UUD 1945 telah membawa perubahan yang sangat mendasar terhadap fungsi Badan Pemeriksaan Keuangan (BPK). Sebelumnya, ketentuan mengenai BPK ini hanya diatur sekilas dalam Pasal 23 ayat (5) UUD 1945 yang menyatakan:" Untuk memeriksa tanggung jawab tentang keuangan negara diadakan suatu Badan Pemeriksaan Keuangan, yang peraturannya ditetapkan dengan undangundang. Hasil pemeriksaan diberitahukan kepada Dewan Perwakilan Rakyat". Pasal ini berada dalam Bab VIII tentang Keuangan. Tetapi sekarang diatur berdasarkan perubahan ketiga UUD 1945 yang disahkan pada tahun 2001, hal ini diatur dalam bab tersendiri, yaitu Bab VIII A mengenai Badan Pemeriksaan Keuangan yang terdiri atas Pasal 23 E, Pasal 23F, Pasal 23 G. 19

Berdirinya Mahkamah Konstitusi di Indonesia dimulai dengan diadopsinya ide Constitutional Court dalam perubahan UUD 1945 yang dilakukan MPR pada tahun 2001. Perkembangan ide pembentukan MK dapat dikatakan relatif baru dan merupakan salah satu perkembangan kreasi dan pemikiran hukum dan kenegaraan modern yang muncul pada abad ke-20.20 Jadi salah satu ketentuan baru yang sangat penting yang terdapat dalam Perubahan Ketiga UUD 1945 adalah ketentuan mengenai Mahkamah Konstitusi yang dirumuskan dalam Pasal 24C ayat (1) sampai dengan ayat (6). ${ }^{21}$ Dengan adanya lembaga ini, maka konstitusi harus dijalankan dan tidak dapat lagi diabaikan, dilanggar, atau menjadi pajangan dan simbol belaka, oleh siapapun juga, termasuk oleh penyelenggara negara. Mahkamah Konstitusi menjalankan empat fungsi, yaitu sebagai lembaga pengawal konstitusi, penafsir konstitusi, penegak demokrasi, dan penjaga hak asasi manusia. ${ }^{22}$

\footnotetext{
18 Pasal 14 ayat (1) dan ayat (2)

${ }^{19}$ Ibid.

20 Indonesia tercatat sebagai Negara ke-78 yang membentuk Mahkamah Konstitusi namun menjadi negara pertama di dunia pada abad ke-21 yang membentuk lembaga ini.

${ }^{21}$ Jimly Asshidiqie, Konsolidasi Naskah UUD 1945 Setelah Perubahan Keempat, Jakarta, Pusat Studi Hukum Tata Negara FH-UII, 2002, hal. 40-44.

${ }^{22}$ Kata Pengantar Ketua Mahkamah Konstitusi RI dalam Buku Abdul Mukhtie Fadjar, Hukum Konstitusi dan Mabkamah Konstitusi, Konstitusi Press, Jakarta bekerjasama dengan Citra Media, Yogyakarta, 2006, hlm. vii.
} 
Dalam sistem ketatanegaraan yang diadopsikan dalam UUD setelah perubahan, mekanisme hubungan antarlembaga negara bersifat horizontal, tidak lagi bersifat vertikal. ${ }^{23}$ Hubungan antara satu lembaga dengan lembaga lainnya diikat oleh prinsip check and balances, dimana lembaga-lembaga mempunyai kedudukan yang sedarajat dan saling mengendalikan. Oleh karena posisinya yang sederajat ini, ada kemungkinan dalam melaksanakan kewenangannya timbul perselisihan dalam menafsirkan amanat UUD. Maka dari itu, diperlukan organ tersendiri untuk menyelesaikan sengketa dan hal itu dilakukan melalui mekanisme peradilan tata negara yang ada pada Mahkamah Konstitusi. ${ }^{24}$

Namun muncul permasalahan mengenai pembatasan lembaga negara yang sengketanya dapat diselesaikan oleh MK, karena dalam UUD Negara RI Tahun 1945 tidak menyebutkan atau menjelaskan tentang lembaga negara apa saja yang dimaksud dengan lembaga negara yang kewenangannya diberikan oleh UndangUndang Dasar itu, sehingga hal ini dapat mengundang beberapa penafsiran. Untuk membatasi lembaga negara sebagai Pemohon maupun sebagai Termohon dalam sengketa konstitusional lembaga negara (SKLN), Mahkamah Konstitusi telah mengeluarkan Peraturan Mahkamah Konstitusi (PMK) No. 08/PMK/2006 tentang Pedoman Beracara dalam Sengketa Kewenangan Konstitusional Lembaga Negara. ${ }^{25}$

Perubahan UUD 1945 Pasal $24^{26}$ menentukan bahwa Mahkamah Agung dan badan peradilan di bawahnya dalam lingkungan peradilan umum, peradilan

23 Jimly Asshiddiqie, Sengketa Kewenangan Antar Lembaga Negara, Konstitusi Press, Cetakan Pertama, Jakarta, 2005, hlm 2.

${ }^{24}$ Ibid, hlm 3.

25 Jika merujuk PMK tersebut, ada 2 (dua) hal yang krusial. Pertama adalah menyangkut subjeknya. Dalam PMK tersebut yang dapat menjadi subjek (Pemohon atau Termohon) secara eksplisit adalah DPR,DPD,MPR,Presiden, BPK, Pemda, dan Lembaga lain yang kewenanganya diberikan oleh UUD 1945. Ada masalah dalam PMK ini terutama ketentuan tentang Lembaga lain yang kewenanganya diberikan oleh UUD 1945. Ketentuan ini menjadi ruang terbuka unttuk menafsirkaan lembaga apa saja yang dapat menjadi subjek dalam SKLN ini. Kedua, menyangkut objeknya yaitu kewenangan yang dipersengketakan. Merujuk Pasal 2 ayat (2) kewenangan yang menjadi objek sengketa adalah kewenangan yang diberikan oleh UUD 1945. Berarti tafsiran terhadap ketentuann ini, selama kewennagan itu diatur atau diberikan oleh UUD 1945, maka dapat menjadi objek sengketa. Berdasarkan Pasal 27 ayat (1) c dan ayat (4), Keputusan ditolak karena permohonan tidak beralasan. Sementara itu, terhadap permohonan yang putusannya tidak dapat diterima (niet onvantelijk verklaard) sebagaimana diatur dalam 27 ayat (2), adalah permohonan dimana Pemohon dan/atau permohonannya tidak memenuhi ketentuan sebagaimana diatur dalam PMK No. 08/PMK/2006, dimana Pemohonnya bukan lembaga yang tersebut dalam Pasal 2 ayat (1), dan objek sengketanya bukan kewenangan yang diiberikan oleh UUD 1945, sebagaimana ditentukan oleh Pasal 2 ayat (2). Selain itu permohonaan tidak diterima karena tidak memenuhi syarat adaministrasi sebagaimana ditentukan dalam Pasal 5 ayat (1) PMK No. 08/PMK/2006.

${ }^{26}$ Landasan konstitusional pembentukan Mahkamah Agung di Indonesia. 
agama, peradilan militer, dan peradilan tata usaha negara adalah pelaku kekuasaan kehakiman yang merdeka, di samping Mahkamah Konstitusi, untuk menyelenggarakan peradilan guna menegakkan hukum dan keadilan. Mahkamah Agung adalah badan yang melaksanakan kekuasaan kehakiman yang dalam pelaksanaan tugasnya, terlepas dari pengaruh kekuasaan pemerintah. ${ }^{27}$

Mahkamah Agung dalam arti luas sebenarnya memiliki kewenangan untuk memeriksa dan memutus (a) permohonan kasasi; (b) sengketa kewenangan mengadili (kompetensi pengadilan); (c) permohonan peninjauan kembali (PK) putusan yang telah memperoleh kekuatan hukum yang tepat; dan (d) permohonan pengujian peraturan perundang-undangan (judicial review).

Perubahan keempat UUD 1945 menjelaskan ketentuan mengenai Bank Sentral yang masuk dalam lembaga negara. Pasal 23D menyebutkan bahwa “ Negara memiliki suatu bank sentral yang susunan, kedudukan, kewenangan, tanggung jawab, dan independensinya diatur dengan Undang-Undang". Hal ini dimaksudkan untuk memberikan dasar hukum bagi bank sentral sebagai suatu lembaga yang sangat penting dalam suatu negara yang mengatur dan melaksanakan fungsi kebijakan moneter. Selanjutnya dikeluarkan UU No. 3 Tahun 2004 tentang Perubahan atas UU RI No. 23 Tahun 1999 tentang Bank Indonesia. Pasal 4 menyatakan : (1) Bank Indonesia adalah Bank Sentral Republik Indonesia;(2) Bank Indonesia adalah lembaga negara yang independen dalam melaksanakan tugas dan wewenangnya, bebas dari campur tangan pemerintah dan/atau pihak lain, kecuali untuk hal-hal yang secara tegas diatur dalam UU; (3) Bank Indonesia adalah badan hukum berdasarkan undang-undang ini.

Selain lembaga yang telah dipaparkan di atas, dalam Undang Undang Dasar 1945 juga terdapat lembaga lain yakni Komisi Yudisial, dalam Pasal 24B ayat (1) UUD Negara RI 1945 disebutkan bahwa Komisi Yudisial merupakan lembaga negara yang mempunyai tugas mengusulkan calon hakim agung dan mempunyai wewenang dalam rangka menegakkan kehormatan, keluhuran martabat dan perilaku hakim. Komisi Pemilihan Umum (KPU) merupakan lembaga negara yang dibentuk dengan tugas sebagai penyelenggara Pemilihan

${ }^{27}$ Kekuasaan kehakiman ialah kekuasaan negara yang merdeka untuk menyelenggarakan peradilan guna menegakkan hukum dan keadilan berdasarkan Pancasila demi terselenggaranya negara hukum Republik Indonesia, demikian menurut Undang-Undang Pokok Kekuasaan Kehakiman. 
Umum di Indonesia. Terakhir adalah Tentara Nasional Indonesia (TNI) dan Kepolisian Republik Indonesia sebagaimana tercantum dalam Pasal 30 ayat (3) dan ayat (4), yang bertugas mempertahankan, melindungi, memelihara keutuhan, dan kedaulatan negara. Serta, Kepolisian Negara Republik Idonesia (Polri) sebagai alat negara yang menjaga keamanan dan ketertiban masyarakat bertugas melindungi, mengayomi, melayani masyarakat serta menegakkan hukum.

Berdasarkan pembahasan di atas, maka struktur Lembaga Negara dalam sistem ketatanegaraan RI menurut UUD Negara RI 1945 tidak hanya mencerminkan trias politica yang hanya terdiri kekuasaan legislatif, kekuasaan eksekutif, dan kekuasaan yudisial, tetapi lembaga negara Indonesia terdiri dari MPR, DPR, DPD, Presiden, MK, MA, BPK dan juga lembaga Independen seperti Komisi Yudisial, Komisi Pemilihan Umum, Bank Sentral, serta TNI dan Polri.

\section{Problematika dalam Penyelesaian Sengketa Kewenangan Lembaga Negara di Mahkamah Konstitusi}

\section{Analisis Putusan Mahkamah Konstitusi No. 068/SKLN-III/2004, dengan Putusan Ditolak}

Putusan No. 068/SKLN-III/2004 merupakan putusan dari perkara sengketa kewenangan lembaga negara antara Dewan Perwakilan Daerah (DPD) dengan Presiden dan DPR. DPD sebagai Pemohon yang kemudian dikuasakan kepada 5 (lima) orang anggotanya yaitu I Wayan Sudirta S.H, Ir Ruslan Wijaya, S.E.,M.Sc, Anthony Charles Sunarjo, Muspani,S.H., Ir. H. Marwan Batubara, M.Sc. Termohon dalam perkara ini adalah Presiden sebagai Termohon I dan DPR sebagai Termohon II.

Objek sengketa adalah pemberhentian angggota Badan Pemeriksa Keuangan periode 1999-2004 dan pengangkatan anggota Badan Pemeriksa Keuangan (BPK) periode 2004-2009 telah mengabaikan kewenangan konstitusional DPD sebagaimana ditentukan dalam Pasal 23F UUD Negara RI 1945, yang menyatakan bahwa Anggota Badan Pemeriksa Keuangan dipilih oleh Dewan Perwakilan Rakyat dengan memperhatikan pertimbangan Dewan Perwakilan Daerah dan diresmikan oleh Presiden. Pemberhentian dan 
pengangkatan anggota BPK yang dimaksud Pemohon tertuang dalam Keputusan Presiden (Keppres) No. 185/M Tahun 2004. Intinya, Pemohon mempersoalkan DPR yang telah melakukan pemilihan anggota BPK periode 2004-2009 tanpa melibatkan DPD. Pemohon juga mempersoalkan Presiden karena telah mengeluarkan Keppres No. 185/M Tahun 2004 sebagaimana tersebut di atas. DPD kemudian melalui pengajuan perkara SKLN memohon kepada Mahkamah Konstitusi (MK) untuk memutuskan apakah benar Keppres No. 185/M Tahun 2004 tentang pemberhentian anggota Badan Pemeriksa Keuangan Periode 1999_ 2004 dan pengangkatan anggota Badan Pemeriksa Keuangan Periode 2004-2009 telah mengabaikan kewenangan konstitusional DPD sebagaimana ditentukan dalam Pasal 23F UUD Negara RI 1945.

Dalam perkara ini, Termohon I memberikan keterangan yang pada intinya menyatakan bahwa Keppres No. 185/M tahun 2004 tentang Pemberhentian Angggota Badan Pemeriksa Keuangan Periode 1999 - 2004 dan Pengangkatan Anggota Badan Pemeriksa Keuangan Periode 2004 - 2009 tidak menyalahi ketentuan UUD 1945, undang-undang yang berlaku, serta tidak melanggar kewenangan DPD. Selain itu, ketika pemilihan anggota BPK dilakukan, DPD hasil Pemilu Tahun 2004 belum secara resmi dilantik. Termohon I juga menyatakan bahwa permohonan DPD bukanlah permohonan tetapi pertanyaan kepada MK, apakah benar Presiden telah mengabaikan kewenangan DPD. Kemudian Termohon II juga menyatakan bahwa permohonan DPD kabur dan tidak jelas karena posita dan petitum tidak ada kesesuaian, bahkan jika Pemohon mempersoalkan Keppres, maka tempatnya bukan pada MK karena MK tidak mempunyai kompetensi menguji Keppres.

Pihak terkait dalam perkara ini, Badan Pemeriksa Keuangan menyatakan, meskipun menurut Pasal 23F UUD Negara RI 1945 DPD mempunyai kewenangan dalam pengangkatan anggota BPK akan tetapi proses pemberhentian dan pengangkatan anggota BPK oleh DPR masih mengacu pada Undang-Undang No. 5 Tahun 1973 tentang BPK, dan UU tersebut belum mengadopsi kewenangan DPD. Oleh karena itu pengangkatan anggota BPK periode 2004 - 2009 telah sesuai dengan undang-undang. BPK juga menyatakan, meskipun DPD dilantik tanggal 1 Oktober 2004 dan Keputusan Presiden No. 185/M tahun 2004 tertanggal 19 
Oktober 2004 akan tetapi Keppres tersebut tetap sah karena Keppres tersebut didasarkan pada putusan DPR yang mendasarkan tterhadap Undang-Undang No 5 Tahun 1973.

Dalam Putusan tersebut, MK menyatakan bahwa:

"MK berwenang memeriksa, mengadili dan memutus permohonan yang diajukan DPD. Terkait dengan pernyataan Termohon II bahwa MK tidak mempunyai kompetensi memeriksa Keppres, maka MK menyatakan bahwa terbitnya Keppres yang dipersoalkan terkait dengan kewenangan DPR. MK juga menyatakan bahwa DPD memenenuhi syarat sebagai legal standing dalam perkara ini, demikian juga DPR dan Presiden memenuhi syarat sebagai Termohon dalam perkara sengketa kewenangan lembaga negara ini. Selanjutnya menurut MK, ketika proses pemilihan anggota BPK periode 20042009 memang telah terjadi perubahan mendasar pada UUD, khususnya mengenai BPK terutama dalam Pasal 23F dan Pasal 23G. Akan tetapi perubahan UUD tidak dapat serta merta dapat berlaku, karena dalam pemilihan anggota BPK, perlu ada undang-undang yang sesuai dan hal itu juga tidak dapat serta merta dilakukan karena terkait dengan proses legislasi yang panjang. Maka dari itu, DPR menggunakan UU No. 5 Tahun 1973 dan kewenengan DPR dalam pemilihan anggota BPK periode 2004-2009 tidak bertentangan dengan UUD. Selain itu Presiden juga tidak terbukti mengabaikan kewenangan konstitusional Pemohon sebagaimana didalilkan oleh Pemohon. Maka dari itu, MK memutuskan bahwa permohonan pemohon ditolak seluruhnya."

Secara umum, dalam perkara SKLN di atas baik subjectum litis maupun objectum litis terpenuhi. Subjectum litis dalam perkara ini adalah lembaga negara yang kewenangannya diberikan oleh konstitusi. Baik DPD sebagai Pemohon, dan DPR serta Presiden sebagai termohon merupakan lembaga negara yang diatur dalam UUD Negara RI 1945. Objectum litis dalam perkara ini yaitu soal pemilihan dan pengangkatan anggota BPK yang harus meminta pertimbangan DPD sebagaimana diatur dalam Pasal 23F sehingga kewenangan tersebut merupakan kewenangan konstitusional. Akan tetapi dalam perkara SKLN, yang diuji bukan hanya menyangkut terpenuhinya subjectum litis dan objectum litis. Dalam perkara tersebut ternyata MK juga melihat waktu, proses dan dasar hukum yang digunakan DPR dan Presiden untuk mengangkat anggota BPK periode 2004-2009 dan menurut MK, pengangkatan anggota BPK ketika itu tidak bertentangan dengan UUD. 
Analisis Putusan Mahkamah Konstitusi No. 3/SKLN-X/2012, dengan Putusan Diterima

Sengketa kewenangan lembaga negara lainnya yang telah diputus oleh MK yaitu sengketa antara Komisi Pemilihan Umum (KPU) sebagai pemohon dan Dewan Perwakilan Rakyat Papua dan Gubernur Papua sebagai termohon. Sengketa ini diawali ketika DPRP bersama Gubernur Papua menerbitkan Peraturan Daerah Khusus Provinsi Papua No. 6 Tahun 2011 tentang Pemilihan Umum Gubernur dan Wakil Gubernur, serta DPRP mengeluarkan Keputusan Dewan Perwakilan Rakyat Papua No. 064/Pimp DPRP-5/2012 tentang Penetapan Jadwal Tahapan Pelaksanaan Pemilihan Umum Gubernur dan Wakil Gubernur Provinsi Papua Periode 2012-2017, bertanggal 27 April 2012 yang dianggap Pemohon telah mengambil alih kewenangannya dalam menyusun dan menetapkan pedoman teknis tentang tahapan Pemilihan Umum Gubernur dan Wakil Gubernur Papua.

Sengketa antara KPU sebagai pemohon dan termohonnya adalah DPRP dan Gubernur Papua tercatat dalam register perkara No. 3/SKLN-X/2012. Dalam perkara ini pertama kalinya MK mengabulkan permohonan pengajuan gugatan SKLN. Berdasarkan ketentuan PMK No. 08/PMK/2006 Pasal 2, terlebih dahulu perlu mencermati bagaimana legal standing dari pemohon yaitu KPU dan termohon yaitu Dewan Perwakilan Rakyat Papua dan Gubernur Papua.

Jika melihat legal standing pihak pemohon dan termohon dalam sengketa tersebut maka keduanya memiliki atau memenuhi syarat sebagai lembaga negara yang kewenangannya ditentukan dalam UUD 1945. Hal ini didasarkan pada pertama, kewenangan KPU yang tertuang dalam UUD 1945 Pasal 22E ayat (5) dan ayat (6) yang menjelaskan bahwa "Pemilihan umum diselenggarakan oleh suatu komisi pemilihan umum yang bersifat nasional, tetap dan mandiri", mengenai suatu komisi pemilihan umum dalam UU No. 15 Tahun 2011 tentang Penyelenggara Pemilihan Umum Pasal 1 butir 6 yang menyatakan, "Komisi Pemilihan Umum, selanjutnya disebut KPU, adalah lembaga Penyelenggara Pemilu yang bersifat nasional, tetap, dan mandiri yang bertugas melaksanakan Pemilu". Keberadaan UU ini merupakan delegasi dari UUD 1945 Pasal 22 E ayat (6). Berdasarkan pada alasan tersebut, MK berpendapat keberadaan bahwa KPU diakui sebagai lembaga 
negara yang dapat menjadi pihak untuk bersengketa terkait dengan sengketa kewenangan lembaga negara di Mahkamah Konstitusi.

Kedua, Dewan Perwakilan Daerah Rakyat Papua dan Gubernur Papua. Memperhatikan ketentuan Pasal 4 ayat (1), Pasal 18 ayat (1), ayat (2), ayat (3), dan ayat (4) UUD 1945. Pemerintahan daerah provinsi, daerah kabupaten, dan kota memiliki Dewan Perwakilan Rakyat Daerah yang anggota-anggotanya dipilih melalui pemilihan umum. Lebih lanjut ketentuan Pasal 18 ayat (6) menyebutkan, untuk melaksanakan otonomi dan tugas pembantuan, Pemerintahan Daerah berhak menetapkan peraturan daerah dan peraturan-peraturan lain. Secara umum pemerintah daerah kewenangannya meliputi kewenangan di bidang pemerintahan yaitu fungsi pembentukan kebijakan (policy making function) dilaksanakan oleh DPRD dan fungsi pelaksana kebijakan (policy executing function) dilaksanakan oleh Gubernur/Bupati/Walikota yang behubungan dengan daerahnya masing-masing.

Berdasarkan pada hal di atas maka MK berpendapat bahwa Dewan Perwakilan Rakyat Papua (DPRP) dikatakan sebagai bagian dari pemerintah yang menjalankan fungsi pembentukan kebijakan yang memiliki fungsi yang dipersamakan dengan DPRD, yaitu sebagai pembentuk kebijakan yang dituangkan dalam peraturan daerah. Nama Dewan Perwakilan Rakyat Papua digunakan sebagai penghormatan terhadap hak-hak tradisional masyarakat Papua sebagaimana mandat Pasal 18B UUD 1945 "Bahwa dalam rangka melaksanakan kewenangan konstitusional sebagaimana dimaksud Pasal 18 ayat (6) UUD 1945, DPRP bersama Gubernur Papua menerbitkan Peraturan Daerah Khusus Provinsi Papua (Perdasus)". Oleh karena itu, keduanya memenuhi syarat untuk dijadikan sebegai subjek hukum yang bisa bersengketa di Mahkamah Konstitusi.

Putusan majelis hakim, menyimpulkan bahwa sengketa yang disengketakan merupakan sengketa kewenangan lembaga negara yaitu terkait dengan penyelenggaraan pemilihan kepala daerah dan wakil kepala daerah di Papua. Bahwa kewenangan konstitusional Pemohon sebagai penyelenggara Pemilu Kepala Daerah dan Wakil Kepala Daerah dilaksanakan dengan berpedoman pada ketentuan Pasal 22E UUD 1945 yang secara teknis dijabarkan 
dalam Undang-Undang No. 15 Tahun 2011, Undang-Undang No. 32 Tahun 2004 tentang Pemerintahan Daerah sebagaimana diubah terakhir dengan UndangUndang No. 12 Tahun 2008 tentang Perubahan Kedua Undang-Undang No. 32 Tahun 2004 dan Peraturan Pemerintah No. 6 Tahun 2005 sebagaimana diubah terakhir dengan Peraturan Pemerintah No. 49 Tahun 2008. Menurut konstruksi Undang-Undang No. 32 Tahun 2004, pemilihan Kepala Daerah dan Wakil Kepala Daerah merupakan rezim pemilihan umum di mana kepala daerah dan wakil kepala daerah dipilih dalam satu pasangan calon yang dilaksanakan secara demokratis berdasarkan asas langsung, umum, bebas, rahasia, jujur, dan adil. Oleh karena itu, pemilihan kepala daerah merupakan rezim dari pemilihan umum yang kewenangan tersebut diberikan oleh konstitusi.

Pihak Pemohon dengan dasar argumentasi bahwa pemilihan kepala daerah merupakan bagian dari pemilihan umum, maka itu merupakan wewenang KPU bukan wewenang DPRP, hal ini didasarkan pada Pasal 1 angka 6 yang menyatakan bahwa Komisi Pemilihan Umum, selanjutnya disingkat KPU, adalah lembaga penyelenggara pemilu yang bersifat nasional, tetap, dan mandiri yang bertugas melaksanakan Pemilu. Sedangkan Pasal 1 angka 4 dan angka 5 Undang-Undang No. 22 Tahun 2007 menyebutkan Pemilu Kepala Daerah dan Wakil Kepala Daerah adalah Pemilu untuk memilih kepala daerah dan wakil kepala daerah secara langsung dan penyelenggara pemilihan umum adalah lembaga yang menyelenggarakan Pemilu untuk memilih anggota DPR, DPD, DPRD, dan Presiden dan Wakil Presiden serta Kepala Daerah dan Wakil Kepala Daerah secara langsung oleh rakyat. Dalam UU ini yaitu Pasal 8 ayat (3) dan Pasal 9 ayat (3) juga telah ditentukan bahwa KPU mempunyai tugas dan wewenang dalam penyelenggaraan Pemilihan Gubernur. Oleh karena itu, kewenangan penyelenggaraan pemilihan kepala daerah di Papua merupakan bagian dari kewenangan KPU sebagaimana diberikan oleh UU ini.

Pihak Termohon mendasarkan pada ketentuan Pasal 139 ayat (1) Peraturan Pemerintah No. 6 Tahun 2005 tentang Pemilihan, Pengesahan Pengangkatan, dan Pemberhentian Kepala Daerah dan Wakil Kepala Daerah yang menyatakan, "Pemilihan Gubernur dan Wakil Gubernur di Provinsi Papua dilakukan secara langsung oleh rakyat, yang pencalonannya diusulkan melalui Dewan Perwakilan 
Rakyat Daerah Provinsi Papua, oleh partai politik atau gabungan partai politik yang memperoleh sekurang-kurangnya 15\% dari jumlah kursi Dewan Perwakilan Rakyat Daerah Provinsi Papua atau 15\% dari akumulasi perolehan suara sah dalam Pemilihan Umum Anggota DPRP". Hal ini ditafsirkan bahwa penyelenggara pemilihan kepala daerah merupakan wewenang dari DPRP.

Majelis Hakim memberikan putusan yang menerima permohonan dari KPU sehingga KPU yang mempunyai kewenangan sebagai penyelenggara pemilihan kepala daerah di Papua. Dengan pertimbangan bahwa dalil para termohon yang mengatakan kewenangan penyelenggaraan pemilihan kepala daerah oleh DPRP yang dikatakan sebagai suatu bentuk kekhususan dari diberlakukannya undang-undang otonomi khusus bagi Papua yaitu sebagaimana diatur dalam Pasal 7 ayat (1) huruf a UU 21/2001 yang keberadaannya didasarkan pada Pasal 18 ayat (6) dan 18B UUD 1945, sehingga DPRP dan Gubernur Papua mengeluarkan Peraturan Daerah Khusus Provinsi Papua No. 6 Tahun 2011 tentang Pemilihan Umum Gubernur dan Wakil Gubernur dan Keputusan Dewan Perwakilan Rakyat Papua No. 064/Pimp DPRP-5/2012 tentang Penetapan Jadwal Tahapan Pelaksanaan Pemilihan Umum Gubernur dan Wakil Gubernur Provinsi Papua Periode 2012-2017, bertanggal 27 April 2012 merupakan kewenangan yang sah, menurut pertimbangan majelis tidak dapat diterima dikarenakan penyelenggaraan pemilihan kepala daerah dan wakil kepala daerah bukan bagian dari otonomi khusus yang diberikan kepada Provinsi Papua, hal ini didasarkan pada putusan Putusan No. 81/PUU-VIII/2010, bertanggal 2 Maret 2011, telah menyatakan, pemilihan gubernur dan wakil gubernur oleh DPRP, sebagaimana diatur dalam Pasal 7 ayat (1) huruf a UU 21/2001, tidak memenuhi kriteria atau tidak termasuk kekhususan atau keistimewaan yang melekat pada daerah yang bersangkutan, baik karena hak asal-usul yang melekat pada Provinsi Papua yang telah diakui dan tetap hidup, maupun karena latar belakang pembentukan dan kebutuhan nyata diperlukannya kekhususan atau keistimewaan Provinsi Papua sebagai bagian dari Negara Kesatuan Republik Indonesia. Oleh karena itu, kewenangan penyelenggaraan pemilihan kepala daerah di Papua tetap berada pada Komisi 
Pemilihan Umum yang diberikan wewenang secara nasional untuk menyelenggarakan pemilihan umum pada semua tingkatan.

\section{Analisis Putusan Mahkamah Konstitusi No. 2/SKLN-X/2012, dengan putusan} Tidak Diterima

Putusan Mahkamah Konstitusi No. 2/SKLN-X/2012 merupakan perkara SKLN yang diajukan oleh Presiden terhadap termohon DPR dan BPK. Pokok permohonan Presiden dalam SKLN ini terkait dengan ada tidaknya keharusan persetujuan DPR atas rencana Presiden melakukan pembelian 7\% saham PT. Newmont Nusa Tenggara. Dalam SKLN yang melibatkan tiga lembaga negara ini yaitu Presiden (Pemohon), DPR (Termohon I) dan BKP (Termohon II), MK berpendapat hanya Presiden dan DPR yang memenuhi objectum litis sebagaimana dipersyaratkan dalam SKLN. Dalam pertimbangannya MK mengatakan:

"Menurut Mahkamah, objek kewenangan yang dipersengketakan dalam perkara ini yaitu kebijakan Pemohon untuk melakukan pembelian 7\% saham PT. Newmont Nusa Tenggara adalah kewenangan derivasi dari kewenangan atribusi yang terdapat dalam UUD 1945, sehingga kewenangan yang dipersengketakan dalam permohonan a quo termasuk kewenangan yang dapat menjadi objek sengketa dalam SKLN. Oleh karena Termohon I, dianggap oleh Pemohon menghalangi pelaksanaan kewenangannya untuk melakukan pembelian 7\% saham PT. Newmont Nusa Tenggara, maka antara Pemohon dan Termohon I terdapat objek kewenangan yang dipersengketakan sehingga memenuhi syarat objectum litis dalam perkara a quo, sedangkan terhadap Termohon II, menurut Mahkamah, oleh karena kewenangan Termohon II (BPK) adalah hanya melakukan pemeriksaan atas tanggung jawab pengelolaan keuangan negara, maka tidak ada kewenangan yang dipersengketakan antara Pemohon dan Termohon II, sehingga Termohon II tidak dapat diposisikan sebagai pihak yang bersengketa dalam perkara ini."

Dalam perkara ini MK berpendapat bahwa berdasarkan Pasal 4 ayat (1), Pasal 23, dan Pasal 23C UUD 1945, kewenangan Presiden adalah memegang kekuasaan pemerintahan yang dalam kaitan dengan keuangan negara, membuat program kerja tahunan pemerintah yang disusun dalam bentuk RAPBN untuk diajukan dan diminta persetujuan DPR serta mengelola keuangan negara yang telah disetujui DPR, sedangkan kewenangan Termohon I adalah memberikan persetujuan atas RAPBN yang diajukan Presiden dan melakukan kontrol atas pengelolaan anggaran negara yang dilakukan Presiden. Namun, untuk Termohon 
II, MK menilai tidak memenuhi kriteria objectum litis sebagaimana Pemohon dan Termohon I. BPK menurut Mahkamah hanya melakukan pemeriksaan atas tanggung jawab pengelolaan keuangan negara, maka tidak ada kewenangan yang dipersengketakan antara Presiden dan BPK, sehingga BPK tidak dapat diposisikan sebagai pihak yang bersengketa dalam perkara ini. Dalam kesimpulan pertimbangan untuk legal standing MK menyatakan:

"Pemohon memiliki kedudukan hukum untuk mengajukan permohonan sengketa kewenangan dengan Termohon I, dan tidak ada sengketa kewenangan dengan Termohon II."

Senada dengan hal ini Ahli Arief Hidayat mengatakan

"terkait dengan Termohon II (BPK), tidak ada sengketa kewenangan dengan Pemerintah sepanjang menyangkut amanat undang-undang, karena fungsi BPK melakukan audit yang disusun dalam LHP (diperintahkan UU) dan tidak menafsirkan Undang-Undang mana yang dipergunakan."

Akan tetapi, walaupun perkara ini secara subjectum litis dan objectum litis memenuhi kriteria untuk dipersengketakan, MK dalam amar putusannya tidak menerima permohonan Pemohon.

Pada dasarnya kewenangan yang diminta untuk diputus MK adalah tentang kewenangan Presiden c.q Menteri Keuangan selaku Bendahara Negara melalui PIP (Pusat Investasi Pemerintah) berhak untuk melakukan divestasi 7\% saham kepada PT. NNT tanpa harus meminta persetujuan dari DPR karena menurut Presiden hal tersebut merupakan bagian dari kekuasaan pemerintahan yang termasuk pula di dalamnya pengelolaan keuangan negara yang merupakan domain eksekutif. Berbeda pandangan dengan Presiden, DPR menyatakan keberatannya atas hal tersebut, DPR menyatakan sebelum Presiden melaksanakan divestasi 7\% saham kepada PT.NNT yang diwakili oleh Menteri Keuangan selaku Bendahara Negara melalui Pusat Investasi Pemerintah (PIP), perlu meminta persetujuan terlebih dahulu kepada DPR selaku perwakilan dari rakyat Indonesia.

MK mempertimbangkan tiga hal, yaitu: pertama, PIP merupakan BLU menurut ketentuan undang-undang. BLU dibentuk untuk meningkatkan pelayanan kepada masyarakat dalam rangka memajukan kesejahteraan umum dan mencerdaskan kehidupan bangsa. Kekayaan BLU merupakan kekayaan 
negara/daerah yang tidak dipisahkan sebagaimana kekayaan Badan Usaha Milik Negara (BUMN). Kedua, PIP merupakan organ hierarkis yang berada di bawah Kementerian Keuangan. Oleh karena posisinya yang demikian, rencana anggaran dan belanja PIP terkonsolidasi dalam rencana anggaran dan belanja Kementerian Keuangan yang menurut Pasal 15 ayat (5) Undang-Undang Keuangan Negara, bahwa APBN yang disetujui oleh DPR terinci sampai dengan unit organisasi, fungsi, program, kegiatan dan jenis belanja. Dengan demikian segala program investasi dan kegiatan PIP harus dimuat dalam rencana anggaran yang dituangkan dalam RAPBN untuk disetujui DPR. Persetujuan DPR menjadi sangat penting agar Presiden c.q. Menteri Keuangan tidak sewenang-wenang atau melampaui batas dalam menggunakan dana investasi atau akumulasi pendapatan PIP, karena PIP bukan perusahaan negara yang kekayaannya dipisahkan. Ketiga, dalam praktik ketatanegaraan Indonesia, khususnya hubungan antara Presiden dan DPR terkait dengan PIP, alokasi dana investasi PIP selalu dimuat secara tegas dalam rencana kerja PIP yang termuat dalam APBN atau telah dibahas dan disetujui bersama dalam pembahasan RAPBN. Dalam hal Presiden hendak menggunakan dana PIP yang belum disetujui DPR, atau selain untuk infrastruktur, Presiden meminta persetujuan DPR, seperti dalam pembelian kembali (buy back) saham BUMN yang telah go public melalui PIP yang telah meminta persetujuan DPR pada tanggal 14 Oktober 2008. Dalam hal ini, Menteri Keuangan sebagai bendahara negara tidak secara otomatis dapat melakukan investasi menggunakan dana PIP dan/atau akumulasi pendapatan PIP selain untuk infrastruktur atau selain untuk program yang telah disepakati dengan DPR dalam pembahasan APBN, atau yang secara spesifik telah disetujui oleh DPR.

Berdasarkan hal tersebut MK menilai karena pembelian divestasi melaui dana PIP di atas berpotensi merugikan negara yang dapat berdampak buruk bagi perkenomian nasional, maka dalam pembelian divestasi dimaksud Presiden harus meminta persetujuan DPR sebagaimana dinyatakan dalam pertimbangannya:

“... penggunaan dana PIP tanpa persetujuan Termohon I mengandung potensi resiko kerugian yang besar yang berdampak pada perekonomian nasional dan potensi penyalahgunaan apabila akumulasi dana PIP yang semakin besar jumlahnya dikelola oleh Presiden c.q. Menteri Keuangan tanpa melibatkan 
Termohon I, walaupun pada sisi lain Termohon I berwenang melakukan pengawasan. Lain halnya, jika PIP merupakan perusahaan negara yang kekayaannya dipisahkan dari kekayaan negara. Dalam perkara a quo, Mahkamah tidak menemukan bukti yang meyakinkan bahwa dana pembelian $7 \%$ saham PT. Newmont Nusa Tenggara tersebut telah dibicarakan dan disetujui oleh Termohon I dalam UU APBN karena ternyata di dalam UU APBN sendiri tidak menyebutkan secara spesifik untuk investasi tersebut."

Lebih lanjut dalam kesimpulan pertimbangan hukum terhadap pokok perkara MK mengatakan:

"Mahkamah pembelian 7\% saham divestasi PT. Newmont Nusa Tenggara adalah kewenangan konstitusional Pemohon dalam menjalankan pemerintahan negara yang hanya dapat dilakukan dengan: (i) persetujuan Termohon I baik melalui mekanisme UU APBN atau persetujuan secara spesifik; (ii) dilakukan secara terbuka dan bertanggung jawab untuk sebesarbesar kemakmuran rakyat; dan (iii) dilaksanakan di bawah pengawasan Termohon I. Oleh karena dana pembelian 7\% saham PT. Newmont Nusa Tenggara belum secara spesifik dimuat dalam APBN dan juga belum mendapat persetujuan secara spesifik dari DPR, maka permohonan Pemohon tidak beralasan hukum."

Oleh karena itu, MK menilai dalam pembelian 7\% saham PT. Newmont Nusa Tenggara yang direncanakan oleh Presiden memang tetap harus mendapatkan persetujuan dari DPR terlebih dahulu. Berdasarkan deskripsi di atas, dapat ditarik kesimpulan bahwa MK tidak menerima permohonan SKLN yang diajukan Presiden bukan karena tidak terpenuhinya syarat subjectum litis maupun objectum litis dari perkara a quo sebagaimana banyak ditemui dalam kasus-kasus SKLN lainnya, melainkan karena MK menilai tidak ada permasalahan konstitusional atas pokok permohonan yang diajukan

\section{Penutup}

Berdasarkan pembahasan di atas, maka dapat disimpulkan bahwa: pertama, struktur lembaga negara dalam sistem ketatanegaraan Indonesia menurut UUD 1945 tidak hanya mencerminkan trias politica yang hanya terdiri kekuasaan legislatif, kekuasaan eksekutif, dan kekuasaan yudisial, tetapi lembaga negara di Indonesia terdiri dari MPR, DPR, DPD, Presiden, MK, MA, BPK dan juga 
lembaga Independen seperti Komisi Yudisial (KY), Komisi Pemilihan Umum (KPU), Bank Sentral yang semuanya mempunyai kewenangan dan tugas masingmasing berdasarkan Undang Undang Dasar 1945. Kedua, problematika terjadi pada Putusan No. 068/SKLN-III/2004. MK menolak permohonan Para Pemohon, bukan pada subjectum litis maupun objectum litis, akan tetapi MK menyatakan bahwa apa yang diperkarakan oleh pemohon tidak melanggar Undang Undang Dasar 1945. Putusan Perkara No. 3/SKLN-X/2012. MK mengabulkan permohonan pengajuan gugatan SKLN. Dalam putusan yang diterima, relatif tidak ada problematika mendasar. Putusan Mahkamah Konstitusi No. 2/SKLNX/2012 Tidak Diterima merupakan putusan sengketa kewenangan antar lembaga negara yang diajukan oleh Presiden terhadap termohon DPR dan BPK. Hal menarik dari putusan ini adalah, subjectum litis-nya terpenuhi, dan ada objek yang disengketakan. Akan tetapi hakim menilai bahwa dalam perkara tersebut sebenarnya tidak ada kewenangan konstitusional.

\section{Daftar Pustaka}

Asshidiqie, Jimly, Konsolidasi Naskah UUD 1945 Setelah Perubahan Keempat, Pusat Studi Hukum Tata Negara FH-UII, Jakarta, 2002.

, Sengketa Kewenangan Antarlembaga Negara, cetakan pertama, KON Press, Jakarta, 2005.

, Perkembangan dan Konsolidasi Lembaga Negara Pasca Reformasi, Sinar Grafika, Jakarta, 2010.

Budiardjo, Miriam, Dasar-Dasar Ilmu Politik, PT. Gramedia Pustaka Utama, Jakarta, 2006.

Gaffar dkk, Janedjri M., Dewan Perwakilan Daerah dalam Sistem Ketatanegaraan RI, Jakarta, 2003.

Huda, Ni'matul, Hukum Tata Negara Kajian Teoritis dan Yuridis Terhadap Konstitusi Indonesia, PSH FH UII kerjasama dengan Gama Media, Yogyakarta, 1999. , Lembaga Negara Dalam Masa Transisi Demokrasi, UII Press, Yogyakarta, 2007.

Irianto, Sulistyowati dan Shidarta (ed.), Metode Penelitian Hukum: Konstelasi dan Refleksi, Yayasan Obor Indonesia, Jakarta, 2009.

Marzuki, Masnur, "Telaah Kritis Kewenangan Mahkamah Konstitusi Dalam Sengketa Kewenangan Lembaga Negara", Jurnal Konstitusi PSHK-FH Universitas Islam Indonesia, Volume IV No. 1, Juni 2011. 
Mukhtie Fadjar, Abdul, Hukum Konstitusi dan Mahkamah Konstitusi, Konstitusi Press, Jakarta bekerjasama dengan Citra Media, Yogyakarta, 2006.

Ringkasan putusan dalam Laporan Tahunan MK Tahun 2009, Mengawal Demokrasi, Menegakkan Keadilan Substanstif, Sekretariat Jenderal dan Kepaniteraan Mahkamah Konstitusi RI, Jakarta, 2009.

Soekanto, Soerjono dan Sri Mamudji, Penelitian Hukum Normatif, Rajawali, Jakarta, 1985.

Putusan Mahkamah Konstitusi No. 68/SKLN-III/2004

Putusan Mahkamah Koonstitusi No. 27/SKLN-VI/2008

Putusan Mahkamah Konstitusi No. 2/SKLN-X/2012

Putusan Mahkamah Konstitusi No. 3/SKLN-X/2012. 